\title{
Por uma estética em língua de brincar: breves reflexões acerca da literatura de Manoel de Barros e de Mia Couto
}

\author{
Maria Auxiliadora Fontana Baseio \\ Uniradial e FIT
}

RESUMO: NOSSO PROPÓSITO NESTE ARTIGO É FAZER REFLEXÕES SOBRE O PROJETO ESTÉTICO DE MANOEL DE BARROS E DE MIA COUTO. AMBOS OS AUTORES, TENDO A LÍNGUA PORTUGUESA COMO INSTRUMENTO, REVELAM UMA CONSCIÊNCIA DE LINGUAGEM ENGENDRADA PELO LÚDICO E PELO MÁGICO, CAPAZ NÃO SÓ DE ENCANTAR O LEITOR, MAS TAMBÉM DE ABRIR CAMINHOS PARA A CONSTRUÇÃO DE UM NOVO PARADIGMA.

ABSTRACT:. OUR PURPOSE IN THIS PAPER IS TO EXAMINE AND GIVE SOME INSIGHT ABOUT THE AESTHETIC PROJECT OF MANOEL DE BARROS AND MIA COUTO. BOTH AUTHORS, HAVING PORTUGUESE LANGUAGE AS AN INSTRUMENT, SHOW AN AWARENESS OF THE ARTISTIC LANGUAGE ENGENDERED BY THE MAGIC AND THE PLAY ELEMENT, WHICH IS ABLE NOT ONLY TO ENCHANT THE READER, BUT TO OPEN PATHS FOR THE CONSTRUCTION OF A NEW PARADIGM.

PALAVRAS-CHAVE: MIA COUTO - MANOEL DE BARROS - LITERATURA - METALINGUAGEM KEY-WORDS: MIA COUTO - MANOEL DE BARROS - LITERATURE - METALANGUAGE SABEMOS QUE, NA HISTÓRIA DAS CULTURAS, A LITERATURA, SEJA EM SUA FORMA ORAL - ORALITURA - SEJA EM SUA FORMA ESCRITA, EXERCEU PAPEL FUNDAMENTAL NA TRANSMISSÃO E NA RENOVAÇÃO DA HERANÇA CULTURAL DOS POVOS. 
ompreendida como arte da palavra, fenômeno de linguagem que expressa a experiência humana, a Literatura, a cada momento histórico, apresenta sua própria concepção de homem, de sociedade, de cultura.

Entretanto, como arte, capaz de se apropriar esteticamente das virtualidades da língua e, como em um jogo desinteressado, revelar um compromisso com a Vida Humana, a Literatura ultrapassa seu contexto histórico de produção, alcançando a atemporalidade.

É com base nessas premissas que propomos algumas reflexões acerca do projeto estético de Manoel de Barros e de Mia Couto, tanto para analisar cada uma das literaturas e das culturas que as alimentam, quanto para sonhar um novo homem para o porvir.

Nossa proposta comparativa compreende ambas as literaturas como componentes de um "macrossistema", no interior do qual nenhuma delas afirmase como paradigmática.

O conceito de "macrossistema" foi assinalado por Benjamin Abdala Junior (2002: 103) e enraíza-se na noção de sistema literário proposto por Antonio Candido.

Para Abdala Junior, os sistemas nacionais articulam-se, formando um todo. Apesar das especificidades de cada um, o macrossistema funciona como um aglutinador das literaturas nacionais consideradas em seu aspecto supranacional, como se constata:

qualquer texto literário em português parte de uma linguagem modelada desde a Idade Média européia, num processo contínuo de aproximações e diferenciações que motivou o contexto comunicativo que se estabeleceu a partir dos tempos coloniais. É dentro dessa dinâmica da comunicação em português, que envolveu, historicamente, constantes semelhantes da série ideológica, que podemos apontar para a existência de um macrossistema marcado por um campo comum de contatos entre os sistemas literários nacionais. (ABDALA JUNIOR, 2002: 203)

A partir da constatação da existência de uma tradição histórico-cultural comum a esses países, os sistemas literários de Brasil e Moçambique participam do macrossistema literário, cuja expressão se dá em língua portuguesa. Como representantes desses sistemas literários, estão Manoel de Barros e Mia Couto. 
Importa-nos, dentro do novo pensamento crítico, ao perceber o mundo como uma realidade de múltiplas fronteiras, buscar o diálogo das culturas, um compartilhamento dos sistemas possibilitado pelo fato de possuírem uma língua comum.

Elegemos, para breve análise, dois textos: "Fontes", retirado do livro $M e-$ mórias inventadas - a terceira infância, de Manoel de Barros, e "Raízes", extraído do livro Contos do nascer da terra, de Mia Couto. Ambos envergam-se para o próprio ventre ficcional em que se gestam os projetos estéticos dos autores, trazendo, como recurso de composição, a metalinguagem.

Metalinguagem deve ser aqui compreendida como a linguagem que se dobra sobre si mesma, revelando-se, portanto, como consciência de linguagem. A poesia que se faz sobre a própria poesia pretende mostrar o ser que ela é; assim como o conto que se dobra sobre sua própria matriz, o mito está no encalço de revelar sua própria essência.

Vale ressaltar que, algumas vezes, a fim de fundamentar nossas idéias, recorreremos a outros textos dos autores analisados.

\section{O projeto estético de Manoel de Barros}

A metapoesia é um dos grandes temas do projeto estético de Manoel de Barros. Ao construir uma poética que se auto-referencia, busca, permanentemente, a origem do poético e de sua matéria. O livro Matéria de poesia é emblemático para a compreensão desse projeto metalingüístico do autor, uma vez que nele concentra a substância de que sua poesia se faz: matéria de poesia para o autor são "as coisas que não pretendem, como pedras que cheiram água, homens que atravessam períodos de árvore", "tudo aquilo que nos leva a coisa nenhuma e que você não pode vender no mercado", "as coisas jogadas fora têm grande importância - como um homem jogado fora", "as coisas sem importância", "o osso da ostra, a noite da ostra” (BARROS, 2005a: 11-15 e 51).

No texto "Fontes", Manoel de Barros anuncia os doadores das fontes de sua arte literária, de suas "memórias inventadas": a criança, os passarinhos e os andarilhos. Aqui, o autor, lucidamente, sintetiza elementos-personagens que servem de eixos fundadores de seu projeto estético, alicerçado em tudo aquilo que o sistema capitalista descarta. Observa-se que faz um resgate do que já se enunciava em "Pelada de barranco", publicado em Memórias inventadas - a segunda infância: 
"Nada havia de mais prestante em nós senão a infância. O mundo começava ali" (BARROS, 2006b). Aliás, o ensinamento do avô é que "os andarilhos, as crianças e os passarinhos têm o dom de ser poesia” (BARROS, 2006b).

Importante contextualizar que o livro Memórias inventadas - a terceira infância (BARROS, 2008), a ser agora abordado, é o terceiro do conjunto, composto por Memórias inventadas - a infância (BARROS, 2003), e Memórias inventadas - a segunda infância (BARROS, 2006b).

Os três livros chegam ao leitor como verdadeiros presentes, oferecidos em uma pequena caixa. Os textos não são encadernados, mas amarrados com laço de fita - revelando uma coerente compreensão por parte da editora a respeito do projeto estético do autor. O próprio suporte comunica, metalingüisticamente, que não se trata de uma mercadoria, mas de um presente artesanalmente elaborado. O projeto editorial conscientiza sobre o projeto estético. Sem costuras, os textos podem ser lidos, de maneira livre e lúdica pelo leitor, aliás este é o responsável por alinhavar as páginas, os sentidos e toda a experiência ali revelada.

Vale elucidar que o título Memórias inventadas remete-nos ao passado, à origem e esse retorno adjetiva-se pela própria invenção. Portanto, memórias inventadas compõem-se como a invenção de um tempo primeiro, como "reinvenção das raízes crianceiras", como o poeta mesmo postula na apresentação da obra analisada.

Passaremos, agora, a analisar cada um dos três elementos apontados como doadores de fontes da obra de Manoel de Barros.

\section{A criança}

A criança é aquela que escreve a cosmovisão do autor, é a voz com a qual ele dá forma a seu projeto estético: "a criança me deu a semente da palavra".

Como criança, é possível exercitar o amor pelas coisas insignificantes, ter deslumbramentos com os mistérios do mundo, brincar livremente com o inominado, compor-se com o princípio da vida, com tudo que inaugura o mundo. Por isso, a criança empresta sua voz ao poeta no exercício de "fazer nascimentos". Interessa-lhe a linguagem da infância, sua afetividade, sua espontaneidade, suas figurações, suas metáforas e analogias, a gramática surreal 
com a qual cria casamentos inesperados entre imagens e sons - o que o poeta chama "delírio do verbo" e que os críticos denominam literariedade.

A criança aproxima-o da oralidade, arma com a qual combate o instituído, o regrado, o legislado, enaltecendo o inventado, o espontâneo. Assim, vai decompondo, des-coisificando a forma até decantá-la em essência. Seu fazer poético se faz mais por encantamento, por intuição, e menos por pensamento: "Não é por fazimentos cerebrais que se chega ao milagre estético senão por instinto lingüístico" (BARROS, 2004: 81). Esse instinto lingüístico é o sêmen da palavra com o qual fecunda sua obra.

Inspira o autor o gesto infantil de pensar maravilhosamente o vivido, a forma mágica de estar no mundo. Daí o encantamento provocado por sua poesia, ao suspender a percepção ordinária do mundo e despertar os sentidos para uma visão extra-ordinária das coisas, ao incursionar pelos espaços ínfimos até atingir grandeza, plasmando realidades que se fazem pelo milagre da invenção.

Manoel de Barros opera com a "semente da palavra", explora a língua em suas raízes, de forma que, para entender sua poesia, é preciso in-corporála, optar pelo caminho da sensibilidade, feito pelo entendimento do corpo - assim mesmo como a criança percebe o mundo - e não pelo caminho da inteligência, porque seus arranjos poéticos são palavras-brinquedos, passíveis de manusear. Distante da linguagem adulta, culta, pensada, afastada do estabelecido, sua linguagem é sentida, tateada, ouvida com total encantamento.

O autor mato-grossense opta por não encarcerar a língua em uma única possibilidade de expressão, organizando sua matéria poética de maneira livre e criativa. Buscando o inominado, o ainda não enclausurado pela regra, ou exilado pela definição, ele não só inventa, mas, sobretudo, des-inventa. No des-inventar, re-apreende a realidade originária, pré-categorial, quase como uma totalidade viva, como a do mito, do rito, dos cantos primeiros, que se manifestaram na infância da humanidade.

O papel da poesia para o autor é abrir à língua outras possibilidades de expressão distintas do ordinário. O ofício do poeta é tirar a língua de seu lugar comum e transportá-la para um lugar festivo de nascedouro, de onde possa brotar novos sentidos e diferentes arranjos, fazendo-nos reconhecer, assim, a literariedade presente e permanente em seu projeto estético. Como revela o narrador da prosa poética "Formação", constante do mesmo livro aqui analisado: "Foi no que deu a nossa formação. Voltamos ao homem das cavernas. 
Ao canto inaugural. Pegamos na semente da voz. Embicamos na metáfora. Agora a gente só sabe fazer desenhos verbais com imagens".

Esse mesmo poder imagético do verbo, em sua manifestação gestual primeira, pode ser reconhecido no início do texto "Fontes: "Três personagens me ajudaram a compor estas memórias. Quero dar ciência delas. Uma, a criança; dois, os passarinhos; três, os andarilhos".

A forma de narrar o texto, misto de canto e conto, revela a possibilidade de a escrita recriar o gesto vocal ou a "performance", no sentido proposto por Zumthor.

Com uma linguagem marcada pela oralidade, Manoel de Barros mostra seu olhar inaugural. Ele, efetivamente, vê com olhos livres, como a criança, que promove a síntese de sujeito e objeto, de homem e natureza. Apartado do olhar comum, bruto, míope, cego, incapaz de ver poesia nas coisas, o poeta brasileiro é portador de um olhar aberto ao invisível, sempre a nos convidar para o exercício de "transver", no precioso sentido do que ele nos ensina ser o des-aprender, o des-ler, no intuito de nos re-ensinar a ler o mundo. Para ele: "o olho vê, a lembrança revê, e a imaginação transvê. É preciso transver o mundo” (BARROS, 2006a: 75). Daí suas memórias serem inventadas.

Avançando para o início de todas as coisas, sua arte poética compõe-se com a magia da voz infantil, valorizando a percepção primeira: o primeiro olhar, o primeiro toque, o primeiro gesto, o primeiro cheiro, o conhecimento primeiro nascido dos sentidos, o olhar de fonte. Flagra gestos primordiais de nossa linguagem e rumores e formas primeiras de nossa língua. Ressoa, em sua arquitetura poética, o início dos cantos do homem, em que se percebe a origem da linguagem. O doador dessas fontes é a criança.

Ao ouvir a VOz das origens, ao rememorar "a semente da língua", o leitor faz um exercício de desaprendizagem do pensar abstrato, adulto, conceitual, aproximando-se cada vez mais da sonhada ignorância, destece os valores impostos pelo capitalismo e pelo paradigma que sustenta a razão ocidental, alarga a visão e descobre possibilidades de transcender, de "desorbitar pela imaginação", por meio da palavra-sêmen, fecundadora de uma nova ordem, capaz de fazer brotar um novo paradigma. A literariedade que alicerça seu projeto estético abre possibilidades de vislumbrar um novo homem, reconciliado com sua natureza e fundado na grandeza de tudo aquilo que se mostra primeiro em qualidade de pensamento, de sentimento e de vontade. 
Seu projeto estético metaforizado pela criança não pretende uma volta linear e repetitiva ao início, mas pressupõe um percurso de ascensão, como se nota:

Ascensão

Depois que iniciei minha ascensão para a infância, Foi que vi como o adulto é sensato!

Pois como não tomar banho nu no rio entre pássaros?

Como não furar lona de circo para ver os palhaços?

Como não ascender ainda mais até na ausência da voz?

(Ausência da voz é infantia, com t, em latim.)

Pois como não ascender até a ausência da voz -

Lá onde a gente pode ver o próprio feto do verbo ainda em movimento.

Aonde a gente pode enxergar o feto dos nomes -

Ainda sem penugens.

Por que não voltar a apalpar as primeiras formas da pedra. A escutar

os primeiros pios dos pássaros. A ver

as primeiras cores do amanhecer.

Como não voltar para onde a invenção está virgem?

Por que não ascender de volta para o tartamudo!

(BARROS, 2005: 41)

Nessa mesma perspectiva sugere: "Eu queria crescer pra passarinho..." (BARROS, 2006: 30).

Passamos, então, à análise do segundo elemento-fonte de seu projeto estético.

\section{Os passarinhos}

Os pássaros são seres extremamente valorizados e recorrentes na obra do autor e manifestam a idéia de liberdade que, ao lado da criança, constitui eixo fundador de seu projeto estético. 
A leveza dos pássaros impulsiona a libertação do peso terrestre, como confirmam os versos do texto analisado: "Os passarinhos me deram desprendimento das coisas da terra".

Pequenos, livres, integrados à natureza, compõem a paisagem primordial, por isso são mais importantes do que uma grande invenção da modernidade, como se lê nos versos do texto "Fontes":

Aprendi com os passarinhos

a liberdade. Eles dominam o mais leve sem precisar

ter motor nas costas. E são livres para pousar em

qualquer tempo nos lírios ou nas pedras - sem se

machucarem.

A liberdade que os pássaros inspiram reflete-se em versos ou frases que compõem a paisagem estética do autor. Além de hibridizar gêneros, rompe com as normas gramaticais em vários sentidos, como a pontuação, suprimindo vírgulas em enumerações, descartando ponto final para concluir frases, entre outras ocorrências, com o intuito de tornar presente o fluxo do pensamento e do sentimento. Seus arranjos libertam-se da lógica sintática e dos princípios de coesão e de coerência.

Nos poemas, prioriza os versos livres e brancos, assegurando a espontaneidade do canto primeiro. Rimas, aliterações, assonâncias re-embalam os sons em sua invenção poética vibrante que apura os sentidos e afina o leitor com os compassos de uma música que se aproxima à linguagem dos pássaros, como mostra em:

Sei também a linguagem dos pássaros - é só cantar.

(BARROS, 2005: 18)

[...] É língua muito transitiva a dos pássaros.

Não carece de conjunções nem de abotoaduras.

Se comunica por encantamentos.

E por não ser contaminada de contradições

A linguagem dos pássaros

Só produz gorjeios.

(BARROS, 2004: 67) 
É essa linguagem musical que ele pretende alcançar, tanto assim que vários títulos de suas obras remetem a essa possibilidade (Arranjos para assobio; Concerto a céu aberto para solos de aves; Cantigas para um passarinho à toa).

Ensina Manoel de Barros (2003: 59): "Minhocas arejam a terra; poetas, a linguagem". Para arejar a linguagem, o poeta brasileiro vale-se de sua vocação para errar na língua portuguesa, para cada vez mais aproximá-la da língua dos índios e das crianças, até transmutá-la à linguagem dos pássaros. Dessa maneira, articula a língua de nosso chão, estendendo-a até a linguagem universal capaz de comungar homem e natureza.

[...] Mas pode uma palavra chegar à perfeição de se tornar um pássaro? Antigamente podia.

$[\ldots]$

Garatujei meus pássaros até a última natureza.

Notei que descobrir novos lados de uma

palavra era o mesmo que descobrir novos lados

do Ser. (BARROS, 2004: 26)

O escritor cria em uma linguagem inventiva, pois, como revela: "a expressão reta não sonha” (BARROS, 2006: 75). E o aprendizado que os pássaros trazem é a disponibilidade para sonhar, conforme o texto "Fontes". Assim, a língua livre e liberta com que projeta seus textos coloca também o leitor em estado de pássaro, concedendo-lhe asas e horizontes, para que perceba outras possibilidades de experiências.

Elo entre a memória dos inícios e o sonho de uma nova ordem, o pássaro é elemento que sintetiza o sonho diurno ${ }^{1}$ de Manoel de Barros: a libertação por meio de uma nova ordem, de outro paradigma capaz de alicerçar, de maneira diferente, as relações humanas. Assim, desenha-se o homem do porvir: um ser livre de imposições, liberto do consumismo, hábil para enxergar o todo, para contrair visão das fontes, para voar livremente e sem limites, para fazer o amanhecer.

1 Conforme Benjamin Abdala Junior, em De vôos e ilhas (2002: 18): "é o sonho de quem procura novos horizontes [...] Essa atitude é mais adequada do que o sonho noturno, que teima obsessivamente em olhar para trás, melancolicamente contemplando as ruínas." - inspirado em Ernst Bloch. 


\section{Os andarilhos}

Andarilho define-se como aquele que percorre terras, de maneira errante, muitas vezes tendo o sentido de mensageiro. Sua maior característica é a ignorância, comunicada por meio de uma linguagem de chão, de natureza, construída por sua relação visceral com a terra. Sua consciência afirma-se pelo não-saber, pela incerteza, pelo imprevisível, pela invenção de novas possibilidades de vivência, porque ele não "afunda estrada, mas inventa caminhos", conforme texto "Fontes".

A língua com que Manoel de Barros constrói seu território estético propõe-se andarilha, porque percorre, descompromissada, caminhos inusitados. Em "Jubilação", texto de Memórias inventadas - a terceira infância, lê-se: "Na faceirice as palavras me oferecem todos os seus lados. Então a gente sai a vadiar com elas por todos os cantos do idioma.[...] Essas vadiagens pelos recantos do idioma seriam só para fazer jubilação com as palavras."

Com essa língua livre e andarilha, que acena, na sua polivalência, para múltiplas possibilidades, para diversos caminhos interpretativos, Manoel de Barros evoca uma forma de leitura pouco disciplinada, nada linear, uma leitura que desejamos denominar também de andarilha, pois exige um leitor livre para escolher a direção e o sentido, um leitor que saiba lidar com o desconhecido, com o imprevisível, com o incerto, com o surpreendente. (E isso a criança e o jovem sabem muito bem.)

Com a imagem do andarilho, Manoel de Barros antevê um novo homem, aquele que não "afunda estrada", mas que se abre voluntariamente à pesquisa de novos caminhos, o que se aventura a novas paisagens e não sucumbe à mesmice programada da vida de consumo. Sua origem e seu destino são o nada, o "oco do mundo", lugar passível de se criarem novas formas. É inocente como criança e profundamente ajustado à natureza - o que o faz conhecer apenas o Ser e não o Ter. Representante da travessia libertária, o andarilho é aquele que, integrado à natureza, pode poetizar. Esse andarilho projeta uma nova forma de estar no mundo. Por isso, apresenta-se como doador de fonte, no projeto estético de Manoel de Barros.

As três personagens - a criança, os pássaros e os andarilhos - anunciadas no texto "Fontes" como colaboradoras das Memórias inventadas, são, de fato, os elementos de sustentação do projeto estético de Manoel de Barros, 
tanto no que se refere ao plano do conteúdo quanto no que se refere ao plano da expressão. Nesse texto, o autor manifesta, em metalinguagem, a mais profunda consciência de seu fazer literário. Sua concepção de literariedade é metaforizada pela criança, pelo pássaro e pelo andarilho, porque expressa a experiência vivida e inventada em língua de brincar, de sonhar e de errar (no sentido de vadiar e de transgredir).

Muitos defendem que o labor poético suspende a práxis. Entretanto, na esteira de Alfredo Bosi (2000: 227), trata-se de uma suspensão momentânea e aparente, pois, ao projetar, na consciência do leitor, imagens do mundo e do homem mais significativas do que as forjadas pelas ideologias, o texto desperta o desejo de uma existência outra e, ao aproximar sujeito de objeto e sujeito de sujeito, acaba por suspender a lacuna que os distancia. Por isso, a transfiguração literária de Manoel de Barros, grávida de literariedade, constitui-se como práxis: toca no corpo, alcança a alma e se inscreve na consciência.

Alquimista da palavra, o autor descarna o verbo até entrever sua estrutura seminal. Com linguagem livre, de língua brincada, opera no mais alto grau da potencialidade estética. Sua poesia transforma a palavra que transforma o homem.

\section{O projeto estético de Mia Couto}

Tomamos, agora, para análise, o texto "Raízes", que compõe o livro Contos do nascer da terra, publicado em 1997.

A narrativa coloca-nos em presença de uma afirmação apaziguadora - " $\mathrm{E}$ foi assim que, por estréia, um homem passou a andar com a cabeça na lua. Nesse dia nasceu o primeiro poeta" - resultante de todo um processo de contemplação, que se converteu em espanto, questionamento, uma curiosidade que se expressou em forma de pergunta: como nasceram os poetas? Após o conjunto de interrogações, a resposta veio de maneira que se tornou impossível formular outra pergunta, porque a resposta configurou-se decisiva. A pergunta quem fez foi o homem, porque necessitou compreender o fenômeno. Eis como Mia Couto intertextualiza a "disposição mental" que serve de estrutura para o gesto verbal designado por Mito.

Segundo Andre Jolles (1976: 89): 
O homem pede ao universo e aos seus fenômenos que se lhe tornem conhecidos; recebe então uma resposta, recebe-a como responso, isto é, em palavras que vêm ao encontro das suas. O universo e seus fenômenos fazem-se conhecer. Quando o universo se cria assim para o homem, por pergunta e resposta, tem lugar a Forma a que chamamos Mito.

Para Mircea Eliade (1994: 11), o mito conta uma história das origens.

[...] o mito narra, como, graças às façanhas dos Entes Sobrenaturais, uma realidade passou a existir, seja uma realidade total, o Cosmo, ou apenas um fragmento: uma ilha, uma espécie vegetal, um comportamento humano, uma instituição. É sempre, portanto, a narrativa de uma criação: ele relata de que modo algo foi produzido e começou a ser.

Conhecer o mito para os primitivos é saber a origem das coisas e dominá-las, manipulá-las. Viver o mito é ter uma experiência verdadeiramente inaugural.

Retomando Andre Jolles (1976: 46):

[...] sempre que uma disposição mental leva a multiplicidade e a diversidade do ser e dos acontecimentos a cristalizarem para assumir uma certa configuração; sempre que tal diversidade, apreendida pela linguagem em seus elementos primordiais e indivisíveis e convertida em produção lingüística, possa ao mesmo tempo querer dizer e significar o ser e o acontecimento, diremos que se deu o nascimento de uma Forma Simples.

O mito está entre essas formas não apreendidas pela estilística, nem pela retórica, nem pela poética, nem mesmo pela escrita. Mia Couto intertextualiza a forma simples do Mito na forma artística do conto, reinaugurando elementos importantes para cultura moçambicana: a tradição oral, a afetividade, o pensamento mágico, a relação do homem com a natureza.

Ao intertextualizar as formas tradicionais da narração, buscando resgatar o intercâmbio físico e afetivo com o outro e revelar a experiência enraizada na escuta, o moçambicano traz à baila a possibilidade de harmonizar o mundo moderno da informação com o mundo sensível das narrações primordiais. 
As culturas fundadas na tradição oral, como a moçambicana, são reconhecidas pela produção artesanal de suas estórias. Ali, o conhecimento é repetido para não se perder. Daí a importância dos velhos, portadores da memória e transmissores dessas experiências dos tempos remotos.

Fazendo ouvir a voz da tradição nas tramas da escrita, Mia Couto recupera a 'performance', entendida aqui na perspectiva de Paul Zumthor. Entretanto, essa performance, que, a princípio, pressupunha o discurso monológico, convive, no conto de Mia Couto, com o discurso polifônico, das várias vozes que participam da narrativa, ressaltando a intencionalidade de criar um território textual fronteiriço, em que o tradicional e o moderno coexistam.

No discurso do narrador, observa-se a conjunção das vozes: "Já ela, desistida, arrumara o facão. Ele, esgotado, pediu que alguém o destroncasse dali. Me ajudem, suplicou. Juntaram uns tantos, gentes da terra [...]”.

Revestido de contador, o narrador faz ouvir, nas curvas das letras, os ecos da oralidade. Com isso, o escritor moçambicano mostra sua resistência a uma ideologia de dominação, que se instaura, sobretudo, pela língua escrita.

No conto em questão, o homem-poeta está enraizado na natureza, criou raízes na terra, para depois ser plantado na lua. A terra é substância universal, considerada a prima matéria, separada das águas, matriz de todas as formas. Antes de ser considerada Deusa-Mãe, divindade da fertilidade, a Terra impôsse, diretamente, como Mãe, 'Telllus Mater'.

Simbolizando a função maternal, a Grande Mãe é aquela que deu origem aos seres, e se identifica, por isso, com a fecundidade, possuindo infinita capacidade de dar frutos. Fonte do ser e dele protetora, ela é mãe nas primeiras experiências. Os homens são ligados a ela, são "gente da terra", ou mesmo "a terra guarda a raiz da gente". Existe uma solidariedade mística com a terra natal, "é a experiência religiosa da autoctonia: as pessoas sentem-se gente do lugar" (ELIADE, s.d.: 150).

No conto analisado, a terra serve de alicerce para o enraizar do homempoeta. $\mathrm{E}$ as radiculações amplificam-se até darem a volta ao mundo:

Até que já um alguém, sabedor de planetas, disse:

- As raízes dessa cabeça dão a volta ao mundo. 
A terra é o lugar de onde fala o poeta, mas suas idéias, por serem arte, ramificam-se para espaços ilimitados. É com páginas da sua terra que Mia Couto constrói suas obras, útero de vozes e letras sensivelmente ouvidas e esculpidas, de modo a assumirem a forma de um entrelugar, um território ficcional capaz de enredar homens de qualquer tempo e espaço.

Entretanto, não basta apenas o elemento telúrico, que representa o racional, o histórico, para compor a natureza da poesia, é necessário, também, o elemento que lhe dá sustentação intuitiva: a lua. Como falou o mais velho: a cabeça dele tem que ser plantada na lua.

Segundo Chevalier (1996), a lua simboliza o princípio passivo, fecundo, a noite, a umidade, o subconsciente ou o inconsciente, a imaginação, o sonho, a intuição, a sensibilidade. É símbolo relacionado à força fecundadora da vida. Ela modela nossa sensibilidade profunda, ligando-se, portanto, às artes.

A zona lunar é lugar das fantasias, da imaginação e da sensibilidade profunda. A ela se entrega o ser em encantamento silencioso, refugiado no paraíso de sua infância, abandonado ao sonho, ao sabor da aventura - lugar da imaginação e da magia.

Os mitos lunares relacionam-se com a morte e a ressurreição, com a fertilidade e a regeneração. A lua nos oferece a vivência de um tempo cíclico, um eterno retorno das experiências, fazendo-nos compreender que nada é estático, tudo começa de novo e é possível ser refeito a cada instante, pois "nenhum acontecimento é irreversível e nenhuma transformação é final", retomando a concepção de Mircea Eliade (1992: 80).

O homem-poeta tem suas raízes plantadas na terra, para que geste racional e historicamente a transformação e é transferido para a lua, para que construa emocional e inventivamente o novo. Esse é o papel do poeta e do escritor moçambicano Mia Couto.

Seus escritos literários, enraizados em vozes da terra, alimentam o leitor de encantamento e de sonho. E este é ponto de destaque de seu projeto estético, como ele mesmo assume:

[...] o escritor não é apenas aquele que escreve. É aquele que produz pensamento, aquele que é capaz de engravidar os outros de sentimento e de encantamento. Mais do que isso, o escritor desafia os fundamentos do próprio pensamento. Ele vai mais longe do que desafiar os limites do politicamente correcto. Ele 
subverte os próprios critérios que definem o que é correcto, ele questiona os limites da razão. Os escritores moçambicanos cumprem hoje um compromisso de ordem ética: pensar este Moçambique e sonhar outro Moçambique. [...] esperamos pelo reacender do amor entre a escrita e a nação enquanto casa feita para sonhar. (COUTO, 2005: 63)

Para ele, o escritor tem compromisso com a liberdade. Por isso, sua literatura posiciona o leitor nesse entrelugar, entre a tradição (transmitida, por exemplo, pelo discurso monológico do mito) e a modernidade (traduzida no conto pela polifonia, pela conjunção de vozes), entre a memória enraizada na terra e as possibilidades do vir-a-ser (a transferência para a lua).

O escritor, ao recriar, na escrita, o gesto vocal, a "performance", alinhava, na artesania da letra, os fios de uma voz antiga, que se manifesta como livre expressão de um pensamento imaginante e de uma forma de estar no mundo animada pela afetividade e pela intuição mágica. Vai costurando uma nova forma de viver, que conjuga o velho e o novo.

Eleger o conto como forma privilegiada de seu projeto estético é, no dizer de Laura Cavalcanti Padilha (1995: 33), "uma forma ancestral de resgate simbólico da história”. Essa proposta de fecundar o gesto vocal, o passado e seus referenciais autóctones traduz, nos terrenos da letra, a expectativa de retecer a história vivida nas malhas da estória sonhada - imagem do poeta enraizado na terra e transferido para a lua - buscando atestar, na "sociedade do ter", a permanência de uma "sociedade do ser", para relembrar Paul Zumthor. ${ }^{2}$

Podemos constatar que o texto "Raízes" é relevante entre os Contos do Nascer da Terra. A nova terra só poderá nascer novamente se for capaz de encontrar sua própria identidade e esta só pode ser buscada nas suas próprias raízes: a tradição.

Mia Couto aponta a forma literária em seu nascedouro - o mito. A recriação dessa forma primeira (forma simples), feita por Mia Couto com uma linguagem polifônica e lúdica, abre a possibilidade da convivência da tradição com a modernidade.

\footnotetext{
2 Segundo Zumthor: "Ser 'moderno' é julgar homens e coisas em virtude do que eles têm ou do que lhes falta; é conhecer seus atributos a fim de domar-lhes o uso. Ser 'antigo' [...] é conhecer e julgar em virtude do ser e do nada. Pelo que concerne à poesia, a escritura parece moderna; a voz, antiga. Mas a VOZ 'moderniza-se' pouco a pouco: ela atestará um dia, em plena 'sociedade do ter', a permanência de uma 'sociedade do ser'." (ZUMTHOR, 1993 : 26).
} 
O texto analisado revela a intenção do autor em resgatar a memória narrativa e oralizante dos griots, bem como toda a história do continente africano, que tem, na arte milenar de contar estórias, sua base de sustentação.

Neste conto, verificamos o debruçar-se sobre mito, entretanto, em outros, observa-se a presença de outras formas, marcadas pelo gesto vocal, como lendas, provérbios, adivinhas. Nas ressonâncias da voz, as formas simples da tradição alinhavam-se em letra, fazendo circular o acervo simbólico-imaginário e a mundividência mágico-mítica que funda a cultura africana.

Ao escolher o narrativo como gênero e o conto como forma, o escritor cria uma espécie de tessitura de contiguidade em que se avizinham a "falaescrita" e a "oralitura". Essa escolha apresenta-se como uma espécie de libertação afetiva contra tudo que as culturas legitimadas como hegemônicas insistiram em rasurar.

É característico do estilo do autor acariciar a língua com suas imprevisíveis "brincriações", estabelecendo uma relação com a língua portuguesa de forma a considerá-la como um sistema aberto e, ao mesmo tempo, afetivo.

No dizer de Ana Mafalda Leite, em Prefácio ao livro de Fernanda Cavacas, no limiar entre "o normativo e o criativo", Mia Couto constrói sua ponte, um entrelugar de reflexão trans(lingüístico), traduzindo este desvairamento "brincriativo" existente há muito no falar cotidiano da língua (cf. CAVACAS, 1999: 7). Essa é a maneira de o escritor nos apresentar um discurso novo.

Por meio das subversões morfológicas, sintáticas e semânticas, o autor inventa diálogos entre a vida vivida e a vida sonhada, aproximando tradição oral de tradição literária.

Essa opção por recursos literários renovadores da dimensão afetiva própria do conhecimento mágico favorece a aproximação dessa literatura com a criança e com o jovem. Assim, concede ao leitor a possibilidade de viver experiências que alinhavam formas distintas de perceber a realidade e de pensá-la.

Consciente de seu fazer estético, o autor moçambicano aponta possibilidades-sonhos de mudança e ajuda a mudar. A verdadeira mudança para Moçambique consiste em costurar os fios da modernidade no tecido da tradição. Evidentemente, isso não deve valer só para Moçambique...

No limite entre o infantil e o adulto, entre o concreto e o abstrato, entre a moral da estória e as indagações sobre o sentido da vida, no entretempo construído pela convergência da tradição e da modernidade, o escritor faz 
vislumbrar um entrelugar estético em que se trançam os mais profundos sentidos de sua literatura: “o escritor não é apenas aquele que escreve. É aquele que produz pensamento, aquele que é capaz de engravidar os outros de sentimento e de encantamento" (COUTO, 2005: 63).

Manoel de Barros e Mia Couto em tempos de reciprocidades

Os títulos dos textos analisados - "Fontes" e "Raízes" - permitem-nos afirmar terem os dois autores consciência de seus projetos estéticos, uma vez que desnudam os eixos de sentido que os estruturam. "Fontes" trata dos personagens-doadores de sentido para o projeto estético de Manoel de Barros: a criança, os passarinhos e os andarilhos. "Raízes" aborda a origem do poeta, com seu duplo enraizamento: na terra e na lua e, ao mesmo tempo, o nascedouro da própria tradição literária - a tradição oral do mito.

Os dois autores mostram, metalingüisticamente, a valorização do homem em seus inícios. O brasileiro arquiteta esse novo homem afirmado nas origens, pela recusa da modernidade e do paradigma vigente; o moçambicano conjuga o novo homem nas fronteiras, buscando costurar tradição e modernidade. Manoel de Barros vislumbra um lugar-primeiro, enquanto Mia Couto acena para um entrelugar.

A voz de Mia Couto ressoa as aspirações de uma sociedade recém-independente, em busca de si mesma e em processo de modernização. Por isso, sua letra, assim como a cabeça do homem-poeta, enraíza-se na terra, no compromisso com suas próprias mazelas, ampliando-se ao universal. Já a voz de Manoel de Barros ecoa os desejos de uma sociedade que vem experimentando, há algum tempo, a independência, portanto pode desconfiar, e a modernidade, por isso pode recusar.

Como recusa à modernidade erguida sobre as bases de um capitalismo selvagem e perverso, Manuel de Barros define a matéria de sua poesia como tudo que é descartado do sistema: a criança, o animal (passarinho), o andarilho, a própria poesia. Mia Couto torna matéria literária o próprio conto na sua origem mítica, revelando o papel do poeta, como homem de fronteira, que transita entre a terra e a lua, no limite entre o racional-histórico e o intuitivo-ficcional.

Ambos os autores constroem seus projetos literários com consciência de linguagem, atentos à literariedade. Trabalham com a lógica da oralidade, deslocando a escrita de seu centro hegemônico. A espontaneidade da expressão, a inventividade da linguagem, as transgressões afetivas da norma gramatical esta- 
belecida acabam por imprimir aos textos um ritmo e uma visualidade, que recuperam a performance, levando o leitor a uma apreensão corpórea do narrado.

O africano e o brasileiro guardam semelhanças na forma como concebem a língua e na missão de fazer ouvir a magia da voz na artesania da letra. Em seus textos, ouvem-se os ecos do narrador tradicional - o contador de estória ou o 'griot', retecendo a experiência da vida nas tramas da ficção.

Enquanto o homem de Mia Couto está em travessia e necessita resguardar seu passado, o homem de Manoel de Barros necessita reinventar a própria memória. Este projeta aquilo que a cultura ocidental cegou, aquele faz questão de valorizar antes que o progresso e a modernidade rasurem.

Conscientes de sua vocação para encantar pela letra, tanto Manoel de Barros quanto Mia Couto criam territórios imaginários fertilizados pela literariedade. E o fazem por meio da Língua Portuguesa, concebida como acervo aberto a "brincriações" e capaz de lhes oferecer a possibilidade de irmanar suas experiências. Lúdica, afetiva e festiva, a língua, com a qual os autores nos ensinam a lidar com o inaugural, aproxima suas obras tanto da criança quanto do jovem em qualquer tempo e lugar, sensibilizando para a transformação de nossa condição planetária.

Manoel de Barros e Mia Couto abrem-nos os canais da percepção para questionar os efeitos de uma civilização reduzida ao quantitativo, ao dinheiro, ao prosaico, evocando a bandeira de uma sociedade-mundo, que abrigue, no mesmo lar, diferentes vozes. Reinventam um entrelugar motivador do diálogo das culturas, projetando uma nova forma de cidadania - a transfronteiriça e transcultural - e uma nova forma de identidade, enraizada em todo planeta, um pouco andarilha, um pouco reinventada, e sempre em curso.

Se como ensina o fotógrafo-poeta de Manoel de Barros, "a importância de uma coisa há que ser medida pelo encantamento que a coisa produza em nós", de forma que "um passarinho nas mãos de uma criança é mais importante para ela do que a Cordilheira dos Andes" (BARROS, 2006), as literaturas desses dois autores valem nosso próprio amadurecimento, pois nos concedem horizontes para ampliar nosso olhar, reverter valores para construir um mundo enraizado em outro paradigma.

Acreditamos ser a literatura um ventre fecundo capaz de gestar o homem. Os dois autores aqui analisados servem-nos como fontes para encantar e sensi- 
bilizar com qualidade de sentimento, de pensamento e de vontade nossas crianças e jovens, se é que pretendemos transformações nas gerações vindouras.

\section{Referências Bibliográficas}

ABDALA JR., Benjamin. Fronteiras múltiplas, identidades plurais. São Paulo: Senac, 2002. . De vôos e ilhas: literaturas e comunitarismos. São Paulo: Ateliê, 2003.

BARROS, Manoel. Exercícios de ser criança. Rio de Janeiro: Salamandra, 1999. . O fazedor de amanhecer. Rio de Janeiro: Salamandra, 2001. - Memórias inventadas: a infância. São Paulo: Planeta, 2003. . Retrato do artista quando coisa. 4. ed. Rio de Janeiro: Record, 2004. - Matéria de poesia. 5. ed. Rio de Janeiro: Record, 2005a. - Tratado geral das grandezas do infimo. 3. ed. Rio de Janeiro: Record, 2005b. . Livro sobre o nada. 12. ed. Rio de Janeiro: Record, 2006a. - Memórias inventadas: a segunda infância. São Paulo: Planeta, 2006b. . Memórias inventadas: a terceira infância. São Paulo: Planeta, 2008.

BENJAMIN, Walter. Magia e técnica, arte e política: ensaios sobre literatura e história da cultura. Trad. Sérgio Paulo Rouanet. 7. ed. São Paulo: Brasiliense, 1994.

BOSI, Alfredo. O ser e o tempo da poesia. 6. ed. São Paulo: Companhia das Letras, 2000.

CANDIDO, Antonio. Formação da literatura brasileira, v. 1. 8. ed. Belo Horizonte: Itatiaia, 1997.

. Literatura e sociedade. 9. ed. Rio de Janeiro: Ouro sobre Azul, 2006.

CAVACAS, Fernanda. Mia Couto: brincriação vocabular. Lisboa: Mar Além Edição de Publicações e Instituto Camões, 1999.

. Mia Couto: pensatempos e improvérbios. Lisboa: Mar Além Edição de Publicações, 2000.

. Mia Couto: acrediteísmos. Lisboa: Mar Além Edição de Publicações, 2001.

CHAVES, Rita. Angola e Moçambique: experiência colonial e territórios literários. São Paulo: Ateliê, 2005.

; MACEDO, Tânia (Org.). Marcas da diferença: as literaturas de língua portuguesa. São Paulo: Alameda, 2006.

CHEVALIER, Jean; GHEERBRANT, Allain. Dicionário de simbolos: mitos, sonhos, costumes, gestos, formas, figuras, cores, números. Trad. Vera da Costa e Silva et al. 10. ed. Rio de Janeiro: José Olympio, 1996.

COELHO, Nelly Novaes. Literatura infantil: teoria, análise e didática. 6. ed. rev. São Paulo: Ática, 1993.

. Literatura: arte, conhecimento e vida. São Paulo: Peirópolis, 2000. 
COUTO, Mia. Terra sonâmbula. 8. ed. Lisboa: Caminho, 2004. . Pensatempos: textos de opinião. 2.ed. Lisboa: Caminho, 2005. . Contos do nascer da terra. 6. ed. Lisboa: Caminho, 2006.

ELIADE, Mircea. O sagrado e o profano: a essência das religiões. Trad. Rogério Fernandes. Lisboa: Livros do Brasil, s.d. - Mito do eterno retorno. Trad. José Antônio Ceschin. São Paulo: Mercuryo, 1992. - Tratado de história das religiões. São Paulo: Martins Fontes, 1993. . Aspectos do mito. Trad. Pola Civelli. 4. ed. São Paulo: Perspectiva, 1994a. . Mito e realidade. Trad. Pola Civelli. 4. ed. São Paulo: Perspectiva, $1994 \mathrm{~b}$.

JOLLES, André. Formas simples: legenda, saga, mito, adivinha, ditado, caso, memorável, conto, chiste. Trad. Álvaro Cabral. São Paulo: Cultrix, 1976.

LEITE, Ana Mafalda. Literaturas africanas e formulações pós-coloniais. 2. ed. Maputo: Imprensa Universitária Universidade Eduardo Mondlane, 2004.

MATUSSI, Gilberto. A construção da imagem de Moçambique em José Craveirinha, Mia Couto e Ungulani Ba Ka Khosa. Moçambique: Livraria Universitária Universidade Eduardo Mondlane, 1998.

PADILHA, Laura Cavalcanti. Entre voz e letra: o lugar da ancestralidade na ficção angolana do século XX. Rio de Janeiro: EDUFF, 1995.

ZUMTHOR, Paul. A letra e a voz: a "literatura" medieval. Trad. Amálio Pinheiro e Jerusa Pires Ferreira. São Paulo: Companhia das Letras, 1993. 